\title{
Combating corruption in Europe: a stimulus-response approach
}

Gabriela Borz

University of Strathclyde

16 Richmond Street,

McCance Building

Glasgow, G1 1XQ

United Kingdom

E-mail: gabriela.borz@strath.ac.uk

\begin{abstract}
What is the effect of external stimuli in curbing corruption at the national level? This article analyses the intervening impact of EU post-conditionality and GRECO monitoring on countries' anti-corruption record. It finds that "soft governance" has a positive impact and stimulates national responses against corruption. This positive influence increases when is additionally conditioned by strong internal stimuli targeting corruption.
\end{abstract}

Keywords Bulgaria $\cdot$ corruption $\cdot$ EU $\cdot$ GRECO $\cdot$ post-conditionality $\cdot$ Romania 


\section{INTRODUCTION}

The search for measures that can curb and prevent corrupt practices is currently receiving an increased interest across disciplines. Corruption deterrents were so far identified in the form of values, social capital, civil society, civic culture (Mungiu-Pippidi 2013, Peiffer and Alvarez 2015), independent judiciary (Jain 2001) anti-corruption agencies and domestic political willingness (Doig 1995, Quah 2010). Within this line of research, this article investigates the impact of soft governance on the adoption and effectiveness of anticorruption measures. Of specific interest is the impact of EU post-conditionality and of Group of States against Corruption (GRECO) on countries' anti-corruption records.

The implementation of anti-corruption measures depends on geographic, economic and demographic internal factors such as: the size of a country, the size of its population and its GDP per capita. An important prerequisite for the effectiveness of anti-corruption measures is the level of political willingness which is manifested when governments offer funding and staffing to independent anti-corruption agencies (Quah 1984, 2003). Additional intervening factors are the external influence of various institutions such as the Millennium Challenge Corporation (initiated by the US Congress), the EU (via enlargement conditionality and European Neighbourhood Policy) (Mungiu-Pippidi 2015, Spendzarova and Vachudova 2012a).

EU conditionality was partly designed with corruption-deterring in mind; but the accounts of its success are mixed. The EU can bring pressure on governments to adopt institutional reforms but its input is considered to have modest results, especially if the institutional change and performance at the moment of accession was considered unsatisfactory (Sedelmeier 2012, Mungiu-Pippidi 2015). Others, however, consider the positive impact of external incentives and recognize them as a mechanism which "can help galvanize the media 
and civil society and put corruption cases in the spotlight" (Spendzarova and Vachudova 2012b: 8). In addition to this debate, existing research on the process of external conditionality acknowledges the problem of isolating the international factors from the domestic ones in determining the success of anti-corruption reforms (Sasse 2008; Hughes et al. 2004).

This article applies a stimulus-response model to anti-corruption records. Stimuli are actions of national and international political and social actors aimed at evoking anti-corruption responses from national decision makers. The focus is on EU conditionality following accession, in other words on EU post-conditionality and its success at curbing corruption. The article seeks to ascertain whether countries have adopted laws and institutions aimed at downsizing or preventing corruption following EU recommendations (as per EU reports) or through their own political initiative in responding to electoral, civil society or to other international actors' pressure. The analysis provides a systematic account of the timing of reforms and their targets in both Romania and Bulgaria whilst also considering the impact of other international organizations such as GRECO.

\section{External stimuli as corruption deterrents: two competing explanations}

The adoption of anti-corruption national reforms is a desirable starting point. The effectiveness of their implementation and the adoption of preventative measures have lately become the focus of national and international institutions. GRECO has been monitoring countries in their fight against corruption on a voluntary basis since 1999. Most European countries have joined GRECO, some even before joining the EU. The question, therefore, is whether countries' anti-corruption efforts are more effective as a result of the EU monitoring their progress after accession. Of interest is the EU's and GRECO's intervening influence in 
countries' anti-corruption legal efforts. In what follows, two theoretical perspectives will be discussed and two propositions developed.

\section{Ineffective soft governance?}

Soft governance has developed as a response to the challenge of diverse societies and interdependence of political actors and works through cooperative regulation and the setting of joint targets rather than top-down uniform regulation (Smismans 2011). For example, the EU is applying a certain degree of soft governance across complex policies such as cohesion, social employment, environment where cross-national agreement would have been very difficult to obtain. This type of governance however has been evaluated as being inefficient (Bulmer et al. 2007, Copeland and Papadimitriou 2012) due to its lack of enforcement mechanisms. Soft governance makes use of policy instruments such as recommendations, guidelines, targets, agreed objectives or "benchmarks" which are all flexible, nonhierarchical, open and participatory forms of policy development. All these instruments are accompanied by weak peer review and stand separately from the legal process of courts. They also have "limited operational effectiveness when members states are not fully in accord regarding the end goal of a policy" (Buonanno and Nugent 2013: 133). In case of anticorruption policy, the end goal implies its reduction. The effective means towards this goal however is influenced by the national context. The soft instruments are all part of a reflexive process which aid horizontal policy coordination across states, while the details of policy development are left entirely in the hands of the national states.

Previous research has predicted deterioration of compliance with EU law after accession in the former communist states (Ganev 2013). Various other authors emphasized the temporal limits of conditionality in influencing anti-corruption reforms (Sedelmeier 2012, Bohmelt and 
Freyburg 2012). Once a state becomes an EU member, the incentive to comply diminishes. EU has hence decided to extend conditionality and monitoring even after membership for Romania and Bulgaria since 2007. EU post conditionality was set up with the aim of reducing the negative effect of domestic partisan and institutional veto players which might prefer the institutional status quo in place prior to accession.

EU post-conditionality can be categorized as a form of EU soft governance given its soft policy instruments embedded in the Cooperation and Verification Mechanism (CVM). The evaluation and monitoring reports on corruption have the intended effect of applying peer pressure if the performance of countries is poor. The question that arises is whether indeed this peer pressure can make a difference in the fight against corruption. In the case of postconditionality peer pressure manifests itself in the form of criticism and recommendations. These are directed at each country but have no immediate binding consequences and penalties. If we follow the logic of soft governance, EU post-conditionality would be expected to have a low impact with regards to reducing corruption. GRECO monitoring through its evaluation rounds and reports can be included in the same category of soft governance as they do not have a binding effect. GRECO's recommendations require action within 18 months but members are not required to report its observations in the subsequent compliance procedure. Following this line of argument, the proposition to be tested is that, on their own:

P1. External criticism and recommendations have a limited impact on reducing corruption. 


\section{Effective national responses conditioned by internal and external stimuli}

This article argues that an effective national response is conditioned by both external (international) and internal (national) stimuli. The stimuli to curb corruption come from external but also from internal actors and take the form of evaluations (positive and nonpositive) and recommendations. External actors are international organizations such as the EU or GRECO, while internal actors can be non-governmental organizations (NGOs), politicians who initiate legislation or citizens who organize protests against corruption or denounce corrupt practices. The responses refer to the adoption of anti-corruption measures but also to their implementation and effectiveness. The anti-corruption measures involve legislation in the administration and judicial system or clearly labelled laws against corruption.

A stimulus-response model provides a political and temporal account of the context in which post-conditionality and other external recommendations and criticism are applied. Domestic political actors act under both internal (social) and external (international) constraints and their response can translate into effective measures against corruption. The latter includes national strategies against corruption and legislative measures which can tackle both grand and petty corruption. Domestic stimuli such as political willingness and civic pressure contribute to the reduction of corruption even in the absence of external pressures (Peiffer and Alvarez 2015, Mungiu-Pippidi 2013). However, when both internal and external constraints are present, the national response against corruption is expected to be more extensive. Henceforth, the following interactive proposition is advanced:

P2: External recommendations and criticisms contribute to the reduction of corruption when internal stimuli are present. 


\section{Variables}

\section{External stimuli}

The external stimuli are measured by the amount of criticism and recommendations per theme as reflected in official institutional reports from the EU and GRECO. Detailed examples of criticism and recommendations are presented in the online appendix, Table 1. At the time of accession in 2007, both Romania and Bulgaria registered deficits in the field of judicial reform, organized crime and corruption. The EU decided to establish a special "cooperation and verification mechanism" in order to assist the two new members in dealing with the outstanding challenges (European Commission 2015). Consequently, in December 2006, the Commission adopted "benchmarks" which consisted of criteria for assessing the progress registered in the areas of administrative and judicial systems and corruption. The benchmarks were slightly different and adapted to the needs and past performance of each country ${ }^{1}$. Subsequently, the Commission published annual progress reports.

The other anti-corruption external stimulus considered in this article comes from GRECO which is a Council of Europe body which has the aim of helping its members fight corruption. States join on a voluntary basis and agree to be monitored on a regular basis. The monitoring process identifies shortages in national anti-corruption policies and supports states in this endeavour by prompting legislative, institutional and practical reforms. Romania and Bulgaria were amongst the GRECO founding members in 1999 and since then have been subjected to four evaluation rounds.

\footnotetext{
${ }^{1}$ In the case of Bulgaria the 6 benchmarks were mainly set around the need for 'non-partisan investigations into allegations of high-level corruption', measures to fight corruption at the local level and a strategy to fight organized crime. Romania's 4 targets were the investigations of high level corruption as in the case of Bulgaria, but additionally the establishment of an integrity agency and the need for measures aimed at preventing corruption (European Commission 2006a, 2006b).
} 


\section{Internal stimuli}

Internal stimuli generate an impetus in the national fight against corruption and refer to social pressure and political willingness to curb corrupt practices. Social stimuli range from street protests, NGO activity against corruption, a free press monitoring corruption scandals, to individual complaints to the anti-corruption agency. Political willingness means the de facto commitment of elites to curb corruption and is more difficult to measure. It can be identified in the lack of political interference in national agencies against corruption or in the national institutions' commitment to curb corruption. For example, national parliaments can decide to remove the immunity of corrupt politicians to facilitate prosecution. Another indicator of political willingness to fight corruption is a low degree of political vendetta. In other words, corruption cases do not only target opposition parties, but all suspected political actors.

\section{National responses}

The dependent variable is the national responses which refer to official measures adopted in order to reduce and deter corruption. These are the adoption and modifications of laws with clear reference to various forms of corruption or the adoption of national strategies against corruption. Their implementation can be gauged by tracing the number of corruption cases and convictions which have been dealt with by the justice system in every country. The values and interpretation of this proxy measure may be problematic when political vendetta is practiced or when the government is tacitly accepting corruption. In both cases the latter measure will not accurately reflect the level of corruption. This is partly corrected by the World Governance Indicator (WGI) on the control of corruption which reports figures based on the opinions of enterprise, citizen and expert survey respondents. 


\section{Data and empirical strategy}

The data used in this analysis is based on official annual reports published by the European Commission from 2007 until 2014 and by GRECO from 2001 until 2014. The dataset comprises 32 EU reports and 8 GRECO reports which were scrutinized with regards to criticisms and recommendations offered by both institutions to Romania and Bulgaria. ${ }^{2}$ These countries are chosen as case studies because they were the only countries against which the Commission started a post-accession CVM procedure. Both countries have institutional features (party list proportional representation) are linked in the literature with high corruption (Kunicová and Rose-Ackerman 2005). Another reason for their selection is the recent contrasting performance registered by Romania in comparison with Bulgaria (Transparency International 2016, Public Integrity Index 2016). This offers a good opportunity for exploring the reasons behind their distinct records in the fight against corruption.

The content analysis of the above-mentioned documents reports the longitudinal frequency of both criticisms and recommendations per theme as offered by both GRECO and the European Commission. The substantive content of both recommendations and criticisms is monitored across time in order to check the correspondence between external criticisms and national measures adopted.

In order to test $\mathrm{P} 1$, the effectiveness of the external stimuli is measured by the longitudinal change in various indicators of corruption ${ }^{3}$ before and after accession and their sequential

\footnotetext{
${ }^{2}$ The EU CVM reports are published twice a year, while the GRECO reports were released once every three to five years. GRECO analysis is based on meetings with public officials and members of civil society but also the latter replies to questionnaires applied by GRECO. The EU reports are prepared after the Commission organizes expert missions to both countries three times a year. During these visits the experts consult with the government, non-governmental organizations and the Commission's local representative.

${ }^{3}$ The World Governance indicators (WGI) are comparable across time. The Corruption Perception Index as compiled by Transparency International (TI) is comparable only from 2012. For other new indicators such as the Public Integrity Index there is no time series data collected yet.
} 
association with the recommendations and criticisms from the European Commission and GRECO. In order to test P2, the temporal dimension will allow us at least partly to disentangle the effect of national and international stimuli on the intensity of national responses. The substantive (i.e. theme related) longitudinal evolution of criticism and recommendations will be compared with the measures taken at the national level.

\section{Results}

\section{Criticisms and recommendations}

Figure 1 shows the evolution of criticism and recommendations received by Romanian and Bulgarian authorities. The reported percentages show the frequency of criticism and recommendations from each annual report. The time periods for high external criticism and recommendations does not coincide in both countries.

In the case of Bulgaria, the content analysis of EU CVM reports reveals that, the peak of EU criticism happened in 2009, 2011 and 2013. In 2009 Bulgarian authorities were criticised for not having initiated investigations into fraud and corruption. The areas affected by corruption and mentioned by the European Commission in Bulgaria included health, education and a mismatch between police investigations and criminal procedures (European Commission 2009a). A major concern at the time was the high number of killings in relation to crime and corruption and the small number of cases which were investigated by the judiciary.

\section{[fig $1 \mathrm{CVM}$ about here]}

The 2011 Commission reports for Bulgaria conveyed high level of acquittals in cases of organised crime, fraud and corruption. The judiciary was not considered fully accountable and transparent, and the Commission considered that the Bulgarian judiciary needed further 
strengthening following legislative changes. The new specialised department in the Supreme Prosecution Office established in 2006 had shortcomings in its judicial and investigative practices. In 2013 EU concerns were reported, especially about Bulgarian police and judicial appointments. Of particular concern was the very low success rate in fighting organised crime despite new asset forfeiture laws intended to weaken crime structures.

For Romania, the content analysis of Commission CVM reports shows us that the EU postconditionality manifests in diminished criticism by 2014. In comparison with Bulgaria, the magnitude of both non-positive evaluations and recommendations is lower and decreased significantly following accession. The peak of EU criticism for Romania occurred in 2008, 2010 and 2013.

Following EU accession, the Commission reported in 2008 that Romania had a very low number of actual convictions for corruption due to poor administrative capacity which stemmed from a weak legal framework for the adjudication of corruption cases. The result was the absence of consistent and efficient procedures to handle corruption cases (European Commission 2009a). In the 2013 CVM report the Romanian judicial system was described as being ineffective in both administrative and legal terms. Legal inconsistencies and ad-hoc reforms were notified as weak points, together with the absence of judicial competence to tackle corruption in public procurement.

\section{National responses}

In order to test $\mathrm{P} 1$, the first step is to analyse the association between the corruption indicators and the intensity of recommendations and criticism. If post conditionality has a positive effect then we would expect periods of high level criticism to be followed by an 
improved country score in combating corruption. In other words, lower country corruption is expected in the years following those with high criticism from the Commission and GRECO.

As figure 2 shows, periods of improved WGI scores for Bulgaria in 2010 and 2012 do indeed follow periods of criticism. The improved anti-corruption performance as reported by the WGI scores is additionally validated by the Commission reports. Important steps forward were identified by the Commission in its 2010 reports for Bulgaria included the public recognition of allegations of corruption within the judiciary and a public acknowledgment of the need for a judiciary reform through a detailed action plan. Progress in the basic Bulgarian legislative framework was also noted by the Commission in the 2012 CVM report, together with a political commitment to reforms.

[fig 2 WGI about here]

Higher WGI scores (lower corruption) in 2009, 2010 and 2011 are corroborated with evidence of measures adopted by the Bulgarian authorities. In 2009 the European commission reported progress against benchmarks. "In response to the CVM report of July 2008 joint teams counteracting EU fraud, organised crime and corruption and money laundering were set up at the Supreme Cassation Prosecution Office" (European Commission 2009b). Additionally, several legislative reforms were praised, especially The Conflict of Interest Prevention and Disclosure Act of 16 October 2008. This legal measure targets conflict of interest between public functions and private interests.

A similar trend is noticeable for Romania. Low WGI scores are recorded in years preceding high criticism from the Commission. Conversely, improved WGI scores are noted in 2011 and 2014, the years which followed acute criticism from the EU (2010 and 2013 respectively). Despite commitment to reforms not being uniform across political parties by 2009, some progress was reported by the European Commission after that in the organisation 
and staffing of the Romanian judiciary (European Commission 2009a). In the 2012 CVM report, the number of legislative reforms increased and improvement was also noticed in the track record of the persecution in high level corruption cases. This explains considerable improvement in the anticorruption scores in 2013 and 2014.

Figures 1 and 2 show a rather disjointed evolution of the fight against corruption in both countries. Bulgaria performed better compared to Romania from 1997 until 2007 (fig. 2). After accession Bulgaria regressed, especially in 2008 and 2014, while Romania experienced a cyclical evolution. Most years of Romanian improvements after accession were mirrored by Bulgarian regression. It should be noted that both countries were subject to the CVM procedure and both were being monitored by GRECO as well. Overall, Romania showed more progress after accession as also demonstrated by diminished criticism received from GRECO after accession. Bulgaria performed much better in this respect before 2007 (see table 1 Appendix). Even if the evolution of countries' WGI scores is not linear, and even if Bulgaria regressed in 2008 and 2014, figure 2 also shows periods of improvement which altogether cannot completely disqualify the impact of external stimuli. In addition, considering that Romania has made considerable improvement, we therefore have some evidence against P1.

Since GRECO monitoring started, both countries registered noticeable annual improvement until EU accession (fig 2). This is an indication that external pressure helps. The addition of post-conditionality following accession has worked even better for Romania in recent years. The analysis of the substantive content of criticism and recommendations before accession clearly reveals that the legislation adopted by countries after evaluation rounds was related to the criticism and recommendations received from GRECO at the time of each evaluation. 
Table 2 appendix shows that most of the corruption related legislation adopted by Romania before the GRECO round in 2005 corresponds to GRECO's Principles 7 and $3^{4}$ which were the focus of the previous 2001 evaluation round. Romania's application of those principles received substantial criticism in 2001. Furthermore, it is also evident that legislation adopted before each GRECO round is not entirely related to the evaluation principles of the previous round and henceforth shows that countries do not follow exclusively GRECO's recommendation and criticisms. The other legislative initiatives might have been prompted by EU conditionality and post-conditionality or by the national elite.

Table 3 appendix reveals that the legislation adopted after 2007 by both countries was in line with EU post-conditionality benchmarks. Bulgaria performed better after accession but regressed after 2010. What is missing from the Bulgarian response was legislation in line with Benchmark 3 which asks for judicial reform and improvements in efficiency. Romania in exchange adopted legislation in line with more than one benchmark in those years where progress is also noticeable in corruption indicators. It is worth noting that GRECO principles and the EU benchmarks largely overlap (see online appendix). This implies that the two institutions reinforce each other's influence on national responses.

Romania's national response was stronger through the adoption of national anti-corruption strategies for 2005-2007, 2008-2010 and 2012-2015, whilst Bulgaria has never had such a national strategy. ${ }^{5}$ Considering the disjointed evolution of the two countries, if the initial argument behind P2 is correct, we would expect the better Romanian results be conditioned by strong(er) national stimuli. A discussion of the national stimuli in the form of civic and political willingness follows in the next section.

\footnotetext{
${ }^{4}$ GRECO's principle 7 refers to the promotion and specialization of persons or bodies in charge of fighting corruption' and principle 3 refers to the independence and autonomy of all those involved in preventing, prosecuting and adjudicating corruption offences (Council of Europe, 2016).

${ }^{5}$ Amongst the New EU12, other countries which did not adopt a national anti-corruption strategy include Malta, Lithuania, Cyprus, Czech Republic.
} 


\section{Stimulus from citizens and NGOs}

In order to test P2, two national intervening variables are discussed: stimuli from active citizens and levels of political willingness. Anti-corruption civic activism comprises individual responsible citizens willing to fight corruption and to denounce corrupt practices. It also includes popular protest against corruption and the work of national NGOs against corrupt practices. Hence, the national response can be prompted by citizens' engagement and activism. Informed citizens can push forward the agenda of controlling corruption. By 2014, a majority of citizens in Romania knew about the Cooperation and Verification Mechanism $(56 \%)$ while a lower percentage (only 44\%) were informed about it in Bulgaria (Flash Eurobarometer 406, 2014). While noticing improvements, a similarly high proportion of Romanians believed that the EU had a positive impact on improving judicial problems and on combating corruption (73 percent and 67 percent respectively). The proportion of citizens holding the same opinions in Bulgaria was lower by more than 10 percentage points.

The stimulus from Romanian society can also be classified as high with respect to public denunciations to the National Directorate against Corruption (DNA). By 2015, about two thirds of the cases investigated by the anti-corruption agency were reported by citizens (DNA, 2015). There is no clear longitudinal Bulgarian data on the number of cases reported by citizens. However, a net difference between the number of cases reported by the anticorruption institutions and the number of corruption cases identified by the NGOs has been reported (CSD 2012). In 2009 and 2014 Bulgaria received the highest level of criticism from GRECO (see Fig. 1 and table 1 appendix). This is corroborated by the very high percentages of Bulgarians (29 percent in 2014) who admitted giving bribes (CSD 2014: 2). The level of civic action against corruption therefore decreased together with trust in public officials. 
Both Romania and Bulgaria experienced sustained activity against corruption from the late 1990s onwards. The number of registered NGOs appears to be slightly higher and more active in Romania, even though Transparency International started its activity two years earlier in Bulgaria (in 1998). ${ }^{6}$ Several NGOs, however, such as The Expert Forum (EFOR) in Romania are also part of the Open Government Partnership initiative ${ }^{7}$ which provides the platform for a dialogue on strategies and legal drafts between governments and EFOR experts. Other NGOs operate as association of organizations, such as the Alliance for a Clean Romania. Even if Bulgarian NGOs were numerous, by 2009, the year when the European Commission strongly criticised Bulgaria, it was reported that most non-governmental organizations had been captured by politicians (CSD 2009).

Through social media, these civic organizations have been very active in stimulating public protest in both countries. One such event led to the resignation of the Romanian government in November 2014 when one of the public slogans was "corruption kills". Similar protests were organized in Bulgaria in 2013 when part of the civic mobilization and popular protest was organized under slogans such as "Down go the Mafia. Power to Citizens". The February 2013 protests were triggered by indignation with the government when a corrupt figure was proposed to manage the State Agency for National Security (Tsoneva and Medarov, n.d.).

\section{Political willingness}

If the argument of external stimuli being more effective when mediated by internal stimuli is correct, we should expect that national responses and measures against corruption are implemented by all governments irrespective of ideological orientation. By the same reasoning, national agencies against corruption are expected to handle high level cases of

\footnotetext{
${ }^{6}$ In addition to Transparency International, a list of NGOs fight corruption comprises amongst others, in Romania: The Alliance for a Clean Romania (http://sar.org.ro), The Expert Forum (EFOR, http:expertforum.ro), The Organized Crime and Corruption Reporting Project (OCCRP; http: riseproject.ro); and in Bulgaria: The Centre for the Study of Democracy (CSD, www.csd.bg) and its initiative the Coalition 2000 process;

${ }^{7}$ Open Government Partnership, http://www.opengovpartnership.org/, last accessed June 2016.
} 
corruption which target both opposition and government officials. Romanian data show that there was no political vendetta when fighting corruption through the prosecution of high level corrupt politicians, as most cases opened by the DNA involved politicians from both the opposition and the government. By 2014, 44 percent of the politicians accused of corruption (indicted, arrested or convicted) were from the governing party, while the opposition cases amounted to less than half of that (19 percent). The number of cases of grand corruption under investigation by the DNA increased in Romania from 1 case in 2002, to 71 cases in 2009 and 237 in 2014 (DNA 2014). Similarly, the number of prosecutions as reported by the DNA increased from 298 in 2011 to 743 in 2012 and 1051 in 2013 (DNA 2013). This data is positively corroborated by measures which show that judicial independence strengthened, especially after 2012 (ERCAS 2015). Consequently the operational efficiency of the DNA improved considerably in subsequent years.

This trend was not paralleled in Bulgaria where, for example, corrupt politicians were still appointed to high level positions in 2013 (Tsoneva and Medarov, n.d.). Immediately after accession, between 2007 and 2008, the number of criminal prosecutions for corruption and organized crime offences decreased, which was not in line with the actual number of such offences (CSD 2009: 10). Additionally, the low levels of political willingness were revealed by an increase in pressures relating to bribery following accession. The percentage of Bulgarians who were asked for a bribe increased from 18 percent in 2009 to 39 percent in 2014 (CSD 2014: 2). By 2016, the level of judicial independence in Bulgaria was two points lower than in $\operatorname{Romania}^{8}$ (IPI 2016).

\footnotetext{
${ }^{8}$ The IPPI score on judicial independence ranges from $1=$ heavily influenced to $7=$ entirely independent. The Romanian score for judicial independence in 2016 was reported as 5.58 and for Bulgaria 3.5.
} 
In conclusion, these last two sections illustrate that after 2007, both political and civic national stimuli were stronger in Romania than in Bulgaria and, combined with external stimuli, contributed to progress rather than backsliding as it occurred in Bulgaria.

\section{Conclusion}

This article has shown that, "soft governance" in the form of external stimuli can have a positive impact on the adoption of national measures targeting corruption. Additionally the strength and effectiveness of national responses are positively conditioned by the activity of individual citizens and civil society more generally, as well as by the willingness of national political elites to fight corruption.

At least in the short run, EU post-conditionality and GRECO monitoring do have a positive direct impact on national responses against corruption. The comparison of Romania and Bulgaria reveals that the national responses they stimulate are even stronger in conditions of national (internal) political and social willingness to curb corrupt practices. These similar cases in terms of background show that the institutional settings and the fight against corruption at the time of EU accession are not the determining factors on a country's future performance; rather, what is more important is the national political and civic stimuli which develop in each country after accession. The strong impact of the latter has also been seen in early 2017 when demonstrations against corruption forced the Romanian government to repeal a controversial ordinance regulating the abuse of power and conflict of interests.

Soft governance can be effective as an external stimulus in the sense of triggering national responses, which are themselves likely to be more robust when internal stimuli are present. The analysis of external criticism, recommendation and national legislation suggests that countries do respond to external stimuli but even more so in the presence of existing domestic initiatives. These results open the door to larger systematic comparative studies of legislative 
measures against corruption and to detailed process tracing of policy making in this area. 


\section{References:}

Bulmer, S., Dolowitz, D., Humphreys, P. and Padgett, S. (2007) Policy Transfer in European Union Governance: Regulating the utilities. London: Rutledge.

Buonanno, L. and N. Nugent (2013) Policies and Policy Processes of the European UnionLondon: Palgrave.

Copeland, P. and Papadimitriou, D. (eds) (2012) The EU's Lisbon Agenda: Evaluating Success, Understanding Failure. Basingstoke, UK: Palgrave Macmillan.

CSD (2012) 'Corruption and Anti-Corruption in Bulgaria (2011 - 2012) Policy Brief No. 35, November 2014 available at www.csd.bg.

CSD (2014) 'Corruption and Anti-Corruption in Bulgaria (2013 - 2014) Policy Brief No. 46, November 2014 available at www.csd.bg.

CSD The Centre for the Study of Democracy (2009) 'Crime without Punishment. Countering Corruption and Organized Crime in Bulgaria' available at www.csd.bg.

DNA (2014) Raport de activitate 2014. http://www.pna.ro/obiect2.jsp?id=241

DNA (2015) Raport de activitate 2015. Available at: http://www.pna.ro/obiect2.jsp?id=249

DNA Directia Nationala AntiCoruptie (2013) Raport de activitate 2013. Available at: http://www.pna.ro/obiect2.jsp?id=231

Doig, A. (1995) Good government and sustainable anti-corruption strategies: a role for independent anti-corruption agencies? Public Administration and Development, 15: 151-165.

ERCAS European Research Centre for Anti-Corruption and State-Building (2015) Public Integrity and trust in Europe. Berlin: Hertie School of Governance.

European Commission (2009a) Report from the Commission to the European Parliament and the Council on Progress in Romania under the Co-operation and Verification Mechanism.

European Commission (2009b), Report from the Commission to the European Parliament and the Council on Progress in Bulgaria under the Co-operation and Verification Mechanism \{SEC(2009) 1074\}

European Commission (2015) Cooperation and Verification Mechanism http://ec.europa.eu/cvm/

Ganev, V (2013) 'Post-accession hooliganism: Democratic Governance in Bulgaria and Romania after 2007' East European Politics and Societies, 27: 26-44

Hughes, J., Sasse, G. \& Gordon, C. (2004) Europeanization and Regionalization in the EU's Enlargement to Central and Eastern Europe. The Myth of Conditionality (Basingstoke, Palgrave).

IPI Index Integrity public (2016) Available at http://integrity-index.org/ 
Jain, A. K. (2001) “Corruption: A Review,” Journal of Economic Surveys, 15: 71-120.

Kunicová, J. and Rose-Ackerman S. (2005) "Electoral Rules and Constitutional Structures as constraints on Corruption," British Journal of Political Science, 35: 573-606.

Mungiu-Pippidi, A. (2013). Controlling Corruption through Collective Action. Journal of Democracy, 24(1):101-115.

Peiffer, C. and Alvarez, L. (2015) 'Who Will Be the "Principled-Principals" Perceptions of Corruption and Willingness to Engage in Anticorruption Activism', Governance 29(3): 351-369.

Quah, J. S. T. (1984) 'The public policy-making process in Singapore'. Asian Journal of Public Administration, 6:2, 108-126.

Quah, J. S. T. (2003) Curbing corruption in Asia: A comparative study of six countries. Singapore: Eastern Universities Press

Quah, J.S.T (2010)'Defying institutional failure: ;earning from the experiences of anticorruption agencies in four Asian countries' Crime, Law and Social Change 53:23-54

Sasse, G. (2008) "The European Neighbourhood Policy: Conditionality Revisited for the EU's Eastern Neighbours", Europe-Asia Studies, 60(2): 295-316.

Sedelmeier, U. (2012) Is Europeanisation through Conditionality Sustainable? Lock-in of Institutional Change after EU Accession, West European Politics, 35:1, 20-38.

Smismans, S. (2011) From Hamonization to Co-ordination? EU Law in the Lisbon Governance Architecture, Journal of European Public Policy, 18:4, 504-524.

Spendzarova, A. and Vachudova, M. (2012a) 'Catching Up? Consolidating Liberal Democracy in Bulgaria and Romania', West European Politics, 35:1, 39-58.

Spendzarova, A. and Vachudova, M. (2012b) The EU's Cooperation and Verification mechanism: Fighting Corruption in Bulgaria and Romania after EU accession. Swedish Institute for European Policy Studies, March, issue 1.

Transparency International (2016) available at: https://www.transparency.org/

Tsoneva, J. and Medarov, G (n.d.) The Rise of the Rhizomatic Party Form. Available at academia.edu.

UNODC United Nations Office on Drugs and Crime (2014) On track against corruption. Available at: http://www.track.unodc.org/ACAuthorities/Pages/home.aspx 
Appendix:

Table 1. GRECO evaluation rounds for Romania and Bulgaria

\begin{tabular}{|l|l|l|l|l|l|l|l|l|}
\hline Evaluation Round & RO 2001 & $\begin{array}{l}\text { BG } \\
\mathbf{2 0 0 1}\end{array}$ & $\begin{array}{l}\text { RO } \\
\mathbf{2 0 0 5}\end{array}$ & $\begin{array}{l}\text { BG } \\
\mathbf{2 0 0 5}\end{array}$ & $\begin{array}{l}\text { RO } \\
\mathbf{2 0 0 9}\end{array}$ & $\begin{array}{l}\text { BG } \\
\mathbf{2 0 0 9}\end{array}$ & $\begin{array}{l}\text { BG } \\
\mathbf{2 0 1 4}\end{array}$ & $\begin{array}{l}\text { RO } \\
\mathbf{2 0 1 4}\end{array}$ \\
\hline $\begin{array}{l}\text { Recommendations } \\
\text { (\%) }\end{array}$ & 13 & 10 & 11 & 4 & 6 & 7 & 11 & 7 \\
\hline Criticisms (\%) & 21 & 12 & 30 & 16 & 21 & 30 & 26 & 29 \\
\hline $\begin{array}{l}\text { Word count } \\
\text { report (N) }\end{array}$ & 14279 & 10603 & 11085 & 11277 & 38377 & 29359 & 30107 & 28024 \\
\hline
\end{tabular}

Source: GRECO https://www.coe.int/t/dghl/monitoring/greco/documents/index en.asp 


\section{Appendix}

Table 2. Greco evaluation per themes and national measures adopted.

\begin{tabular}{|c|c|c|c|c|c|c|c|c|c|c|c|c|c|c|c|c|c|c|c|c|c|c|}
\hline $\begin{array}{l}\text { Recommendations } \\
\text { (\%) }\end{array}$ & 17 & 10 & 13 & 17 & 17 & 8 & 10 & 11 & 15 & 3 & 6 & 4 & 5 & 8 & 4 & 9 & 12 & 11 & 14 & 9 & 6 & 9 \\
\hline Criticism (\%) & 29 & 28 & 16 & 19 & 15 & 12 & 31 & 38 & 24 & 15 & 21 & 18 & 18 & 26 & 23 & 37 & 72 & 28 & 27 & 40 & 26 & 24 \\
\hline $\begin{array}{l}\text { Laws adopted per } \\
\text { round principles }\end{array}$ & 1 & 5 & 6 & 6 & 0 & 1 & 2 & 7 & 2 & 3 & 2 & 1 & 9 & 9 & 2 & 5 & T1: 1 & & & T1: 1 & & \\
\hline
\end{tabular}

Source: GRECO evaluation rounds: GRECO https://www.coe.int/t/dghl/monitoring/greco/documents/index_en.asp;

National legislation: https://www.acauthorities.org/, www.legislationonline.org, last accessed 2015. 
Figure 1. Evolution of EU criticism and recommendations (\%)

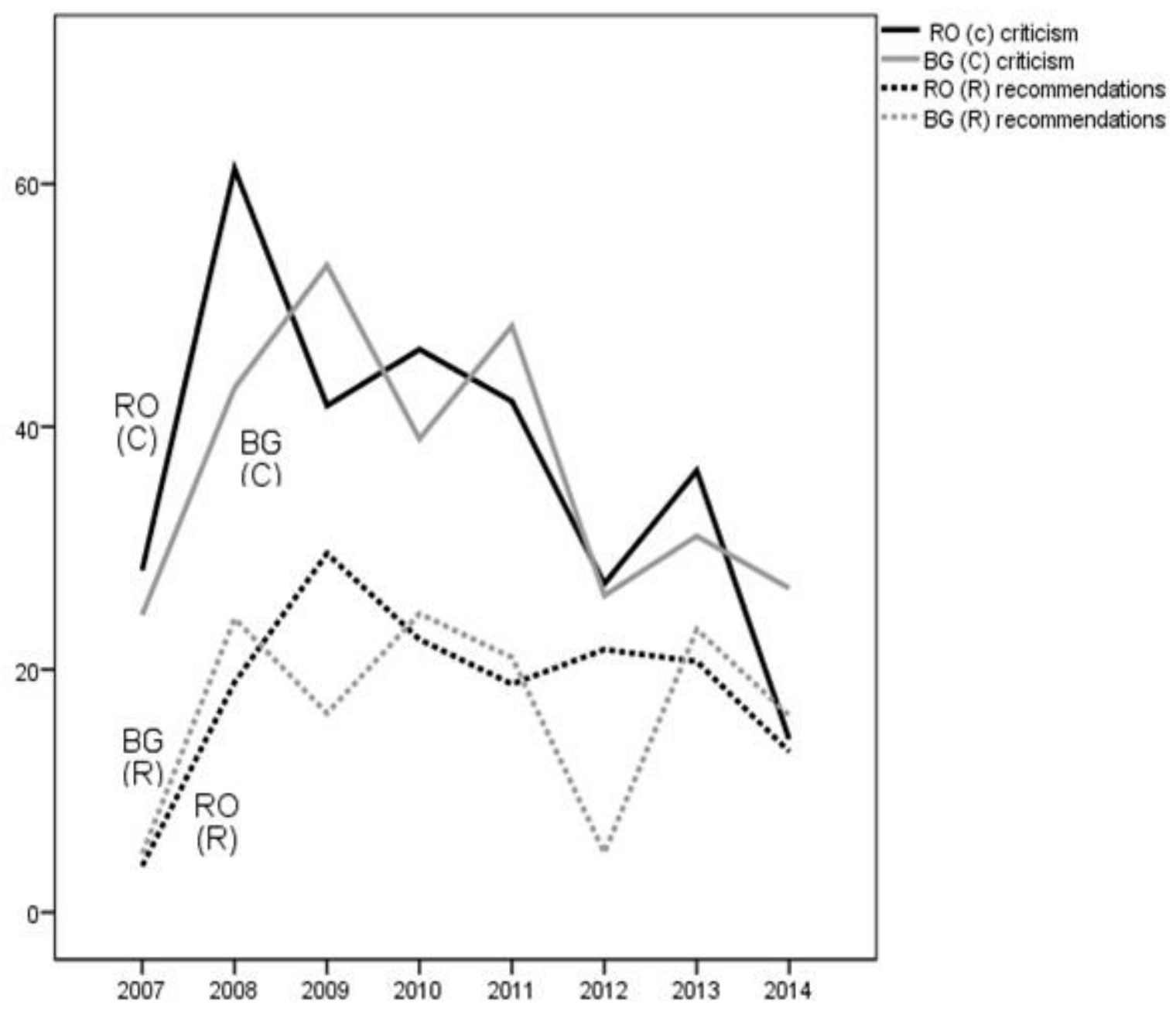

Note: The lines show in percentages the substantive allocation to criticism and recommendations from each annual CVM report. 
Figure 2: Evolution of WGI scores 1996-2014

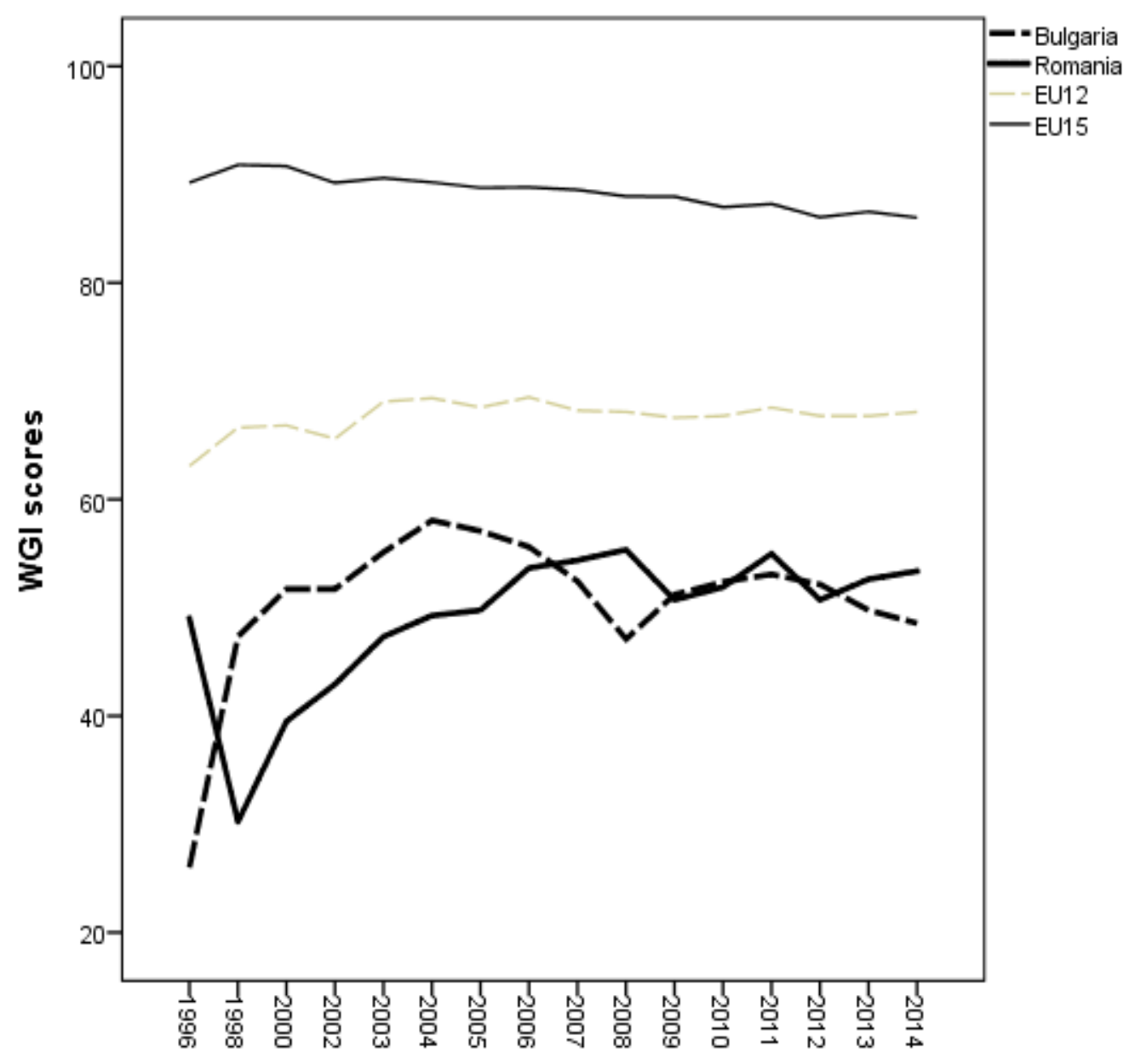

Source: World Bank, World Governance Indicator (Control of Corruption) www.govindicators.org 